DOI: $10.22363 / 2312-9182-2018-22-3-521-538$

\title{
Anna Wierzbicka, Semantic Decomposition, and the Meaning-Text Approach
}

\author{
Igor Mel'čuk \\ Observatoire de linguistique Sens-Texte \\ Université de Montréal \\ Case postale 6128 Centre-ville, Montréal H3C3J7, Canada
}

\begin{abstract}
The paper aims to demonstrate that the main contribution of Anna Wierzbicka to linguistics is the idea of semantic decomposition - that is, representing meaning in terms of structurally organized configurations of simpler meanings - and a huge amount of specific decompositions of lexical meanings from many languages. One of possible developments of this idea of Wierzbicka's is the Meaning-Text linguistic approach, and in particular - the Meaning-Text model of natural language. To illustrate the importance and fruitfulness of semantic decomposition, two Meaning-Text mini-models are presented for English and Russian. Two semantically equivalent sentences of these languages are considered:
\end{abstract}

(1) a. Eng. A honeymooner was fatally attacked by a shark.

b. Rus. Molodožën pogib vrezul'tate napadenija akuly vo vremja medovogo mesjaca lit. 'Young.husband died as result of.attack of.shark during honey month' The formal representations of these sentences at four levels-Meaning-Text style - are shown: semantic, deep-syntactic, surface-syntactic, and deep-morphological. Examples of formal rules relating the representations of two adjacent levels are presented.

Keywords: semantic decomposition, formal linguistic modeling, Meaning-Text approach, semantic representation, deep-/surface-syntactic and deep-morphological representations, linguistic rules

\section{Анна Вежбицкая, семантическое разложение и подход «Смысл-Текст»}

\author{
И.А. Мельчук
}

Обсерватория лингвистики «Смысл-Текст»

Монреальский университет, Канада

6128 Centre-ville, Montréal H3C3J7, Canada

\begin{abstract}
Аннотация
Цель статьи - показать, что главный вклад Анны Вежбицкой в лингвистику — это идея семантического разложения, т.е. представления смыслов в терминах структурированных конфигураций более простых смыслов, равно как и огромное количество конкретных разложений лексических значений различных языков. Одним из возможных развитий данной идеи является лингвистический подход «Смысл-Текст», в частности - модель «Смысл-Текст» естественного языка. В качестве иллюстрации важности и плодотворности семантического разложения предлагаются две минимодели «Смысл-Текст» - для английского и русского языков. Рассматриваются английская и русская семантически эквивалентные фразы:
\end{abstract}

(1) a. Eng. A honeymooner was fatally attacked by a shark.

b. Rus. Molodožën pogib v rezul'tate napadenija akuly vo vremja medovogo mesjaca. 
Для этих фраз приводятся формальные представления, принятые в модели «Смысл-Текст», на четырех уровнях: семантическом, глубинно-синтаксическом, поверхностно-синтаксическом и глубинно-морфологическом. Даются примеры формальных правил, соотносящих представления соседних уровней.

Ключевые слова: семантическое разложение, формальное моделирование языков, подход «СмыслТекст», семантическое представление, глубинно-/поверхностно-синтаксическое и глубинноморфологическое представления, языковые правила

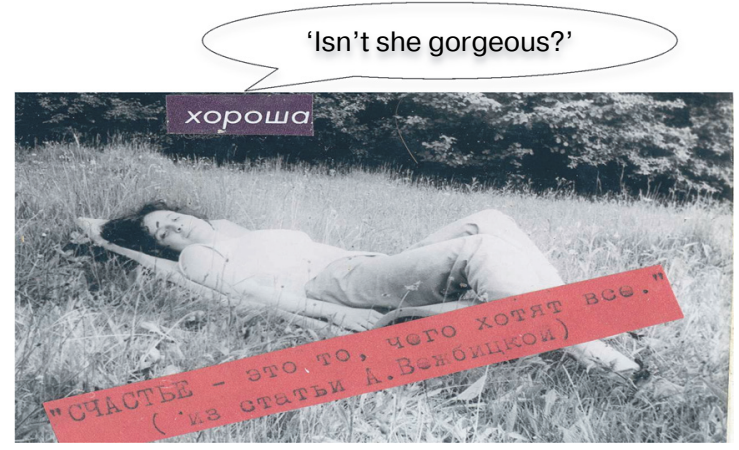

"HAPPINESS is what everybody wants" [Anna Wierzbicka] Anna Wierzbicka in Moscow (more than half a century ago), during a pleasure hike in the countryside. For a more substantiated semantic decomposition of 'happiness', see Goddard \& Wierzbicka 2014: 102ff.

\section{THE QUESTION: WHAT DID ANNA WIERZBICKA GIVE US?}

A few important words and deeds in the history of Humanity: God is known to have uttered His famous announcement Yehi or! 'Let.there.be light!' (if He spoke Hebrew) and created the Universe. Closer to us, Gaius Julius Caesar declared Alea jacta est! 'The.dice are cast!', and Vespasian let us know that Pecunia non olet 'Money has no smell'. Archimedes said Eureka! 'I have found it!', Copernicus discovered the fact that the Earth was orbiting the Sun, Galileo established the notion of inertia, and Newton laid the foundations of modern physics by formulating the three Main Laws of Motion. Mendeleev created the Periodic Table of Elements ${ }^{1}$, and Einstein, the Theory of Relativity; etc. That is what all these great people left the humanity. The question asked in this paper is direct and quite simple:

| And Anna Wierzbicka, what has she given us?

\section{THE ANSWER: ANNA WIERZBICKA GAVE US SEMANTIC DECOMPOSITION}

My answer to this question is also direct and quite simple:

First and foremost, Anna Wierzbicka has given the world semantic decomposition.

NB: From now on, "Anna Wierzbicka" $\Rightarrow$ "AW."

It is quite possible that AW herself would not agree with me: this could be for two reasons. 
First, as far as I can judge, AW's main thrust in semantics was from the very beginning - and remains! - to discover the Semantic Primitives of human thought, linguistically universal semantic elements, or Semantic Primes, as they have come to be known lately, and, based on these, to elaborate a universal Natural Semantic Metalanguage (see, for instance, the latest monograph I know of: Goddard \& Wierzbicka 2014). This is, no doubt, an extremely important and promising task, and AW would probably object to my putting semantic decomposition over it.

Second, there is a huge number of other paramount contributions from AW (about these, see, for instance, a concise and precise exposition in Padučeva 1996): the nature of linguistic meaning, semantics of grammar (Wierzbicka 1988), language-imposed categorization of entities and facts, semanticization of pragmatics and syntacticization of the semantic metalanguage, etc. Wierzbicka elaborated some basics of semantic metalanguage for chimpanzees (Wierzbicka 2014a: 156-181), explained what Jesus meant by his Sermon on the Mount (Wierzbicka 2001) ${ }^{2}$, solved the mysteries of Immanuel Kant's Categorical Imperative (Wierzbicka 2014b), described many dozens of linguistic-cultural scripts (e.g., Wierzbicka 1992), and has to her credit many more linguistic results of the highest order.

Yet I will concentrate just on one aspect of AW's achievements:

the representation of linguistic meaning in terms of structurally organized configurations of simpler discrete linguistic meanings, which is called semantic decomposition.

I believe that everything else follows, more or less, from this key element. Indeed, if we stick to decomposing the meanings of words in terms of the meanings of other words and do this according to a few basic logical rules, such as banning logical circles, we unavoidably end up with some indecomposable meanings - semantic primitives. Semantic decomposition allows the linguist to treat linguistic meaning as a formally describable substance and thus opens the gate to the construction of formalized linguistic models. At the same time, it draws the linguist's attention to every semantic detail, not only in the lexicon domain, but in the grammar as well. A formal description of meaning - that is, semantic decomposition - forces the researcher to consider speech production as a translation between the representation of meaning and the representation of text - and, in this way, lays the foundation of the Meaning-Text approach.

In a word, semantic decomposition has started a new era in linguistic semantics and, more generally, in linguistics, since language is but a device designed to express meanings. Semantic decomposition, or the systematic insistence on the "molecular structure" of linguistic meaning, played the same liberating and fertilizing role in linguistics as the atomic-molecular theory, developed in the $19^{\text {th }}$ century by Dalton, Avogadro, Maxwell and many others, in chemistry and physics. Can one imagine modern hard sciences without atoms and molecules? In the not so distant future, linguistics will not be imaginable without semantic decomposition. (And not only linguistics, but also all sciences intimately related to human language - anthropology, ethnology, psychology, etc., in fact all humanities.)

True, AW was not the first to launch the idea of semantic decomposition: in Wierzbicka 1972: 3-12, she herself scrupulously enumerates her predecessors from Descartes, Leibnitz and Locke to Frege, Sapir and Hjelmslev to Andrzej Bogusławski, 
Alexander Žolkovskij ${ }^{3}$ and Jurij Apresjan. However, it was AW who injected the idea into the conscience of linguists - through an unbelievable amount of descriptive work. A really mind-boggling quantity of semantic analyses has been made available: thousands of lexical units and scores of grammatical values in dozens of languages — from Polish and Russian to English, German, Italian, Spanish and French to Japanese, Philippines' Ilongot, Californian Kashaya and Australian Ompela.

To sum up: "Who says AW, says semantic decomposition; who says semantic decomposition, says AW." The idea of semantic decomposition and the formal description of linguistic meaning in terms of discrete semantic units has become the cornerstone of modern semantics. This idea has entered contemporary linguists thanks to AW's fundamental work.

\section{SEMANTIC DECOMPOSITION AS THE BASIS FOR FORMAL LINGUISTIC MODELING: MEANING-TEXT THEORY}

\subsection{Introductory Remarks}

In order to shed more light on the importance of semantic decomposition, I would like to demonstrate one particular natural outgrowth of the acceptance of semantic decomposition as a founding principle. Thereby, I will show how linguistics can be turned into a genuine hard science-by making linguistic meanings as formally representable as linguistic forms and by making the rules relating meanings and forms "computable." To do so, I will present, in a concise outline, the theory of Meaning-Text linguistic models, developed in close collaboration between Alexander Zholkovsky and myself. Our joint work on a Meaning-Text model of Russian started in early 1960s (Žolkovskij \& Mel'čuk 1965, 1966, 1967), essentially based on a series of Zholkovsky's proposals (Žolkovskij et al. 1961, Žolkovskij 1964a-c). Soon afterward, we were joined by Jurij Apresjan (see, for instance, Apresyan et al. 1969) and several other colleagues and the Moscow Semantic Circle was born (see Apresjan 1974, 1992 and Mel'čuk 1974). With it came along a concerted effort on a Russian Explanatory Combinatorial Dictionary (Mel'čuk \& Zholkovsky 1984, Mel'čuk \& Žolkovskij 2016) and on other aspects of a Meaning-Text model of Russian and then of English and French. A parallel development, but pushed much further in terms of the vocabulary covered as well as the wealth and refinement of lexicographic information, is Apresjan's Aktivnyj slovar' russkogo jazyka [Active Dictionary of Russian] (Apresjan, ed. 2014).

I will present — in parallel — two formal Meaning-Text mini-models: for English and for Russian. Put in a nutshell, within the Meaning-Text approach, linguistic modeling is conceived of as comprising two major tasks:

- Elaborating formal representations of sentences at different levels: semantic representation [SemR], two syntactic representations (deep- and surface-) [DSyntR, SSyntR], two (also deep- and surface-)morphological representations [DMorphR, SMorphR], and deep- and surface-phonic representations [DPhonR, SPhonR]. The SemR stands for "Meaning," while the SPhonR - that is, phonetic representation — stands for "Text".

- Elaborating rules that relate these representations.

These two tasks will be considered in turn. 
It is impossible to introduce here the tools and the formalisms of the Meaning-Text approach, including all necessary notions, terms and notations. On the one hand, I rely on the principal references: Mel'čuk 2012b, 2013, 2015, 2016; on the other hand, I hope that in most cases my illustrations are self-explanatory. (However, I add local explanations wherever I feel necessary.)

\subsection{Meaning-Text Formal Representations of Sentences}

Consider English sentence (1a) and its Russian equivalent (1b), chosen to be semantically and syntactically as close as possible. (However, each has many possible paraphrases, so that a host of other equivalences are of course possible.)

(1) a. Eng. A honeymooner was fatally attacked by a shark.

b. Rus. Molodožën pogibvrezul'tate napadenija akuly vo vremja medovogo mesjaca lit. 'Young.husband died as result of.attack of.shark during honey month'

The task of synchronic linguistics is to devise formal rules that ensure the transition between the meanings of these two sentences and the sentences themselves; or, which amounts to the same thing, to devise rules for the transition between these two sentences and any other such pairs. But how to formulate such rules if sentences (1a) and (1b) look so different? Let us draw their formal representations - semantic, deep-syntactic, surface-syntactic, and deep-morphological (closer-to-surface representations - that is, the surface-morphological and the two phonic ones - are irrelevant to our purposes here). It will immediately be clear that the correspondence between the SemR of the English sentence and that of its Russian counterpart can be stated in terms of formal rules. The same rules allow to map each of these SemRs to the corresponding syntactic and morphological representations, closer to the linguistic surface.

\subsubsection{Meaning-Text Semantic Representation of Sentences}

(2) Semantic Representations [SemRs] of Sentences (1a) and (1b)

NB: These representations are incomplete: the meanings of semantically-loaded morphological values (grammemes, such as the number and definiteness of nouns and the mood, voice, tense and aspect of verbs) are not shown.
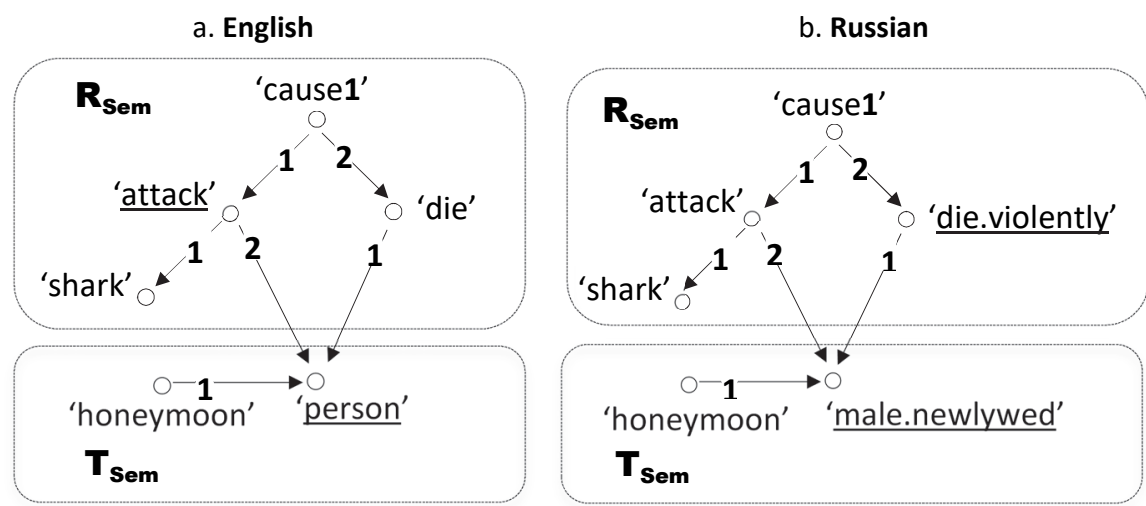

\section{Comment}

A SemR of a sentence is a set of four structures, of which only two are shown in (2a-b): a semantic structure and a semantic-communicative structure. In order to simplify, I omit the rhetorical structure, which specifies the stylistic character of the 
sentence to be produced, and the referential structure, which makes explicit the links between semantemes - lexical meanings of the language under consideration - and semanteme configurations, on the one hand, and their referents in the extralinguistic world, on the other. (NB: For simplicity's sake, I violate the fundamental principle that the semantic decomposition of lexical meanings of a language must be done in terms of lexical meanings of this language; I allow myself to use English semantemes in the Russian SemR, which, in this case, does not distort the intended picture.)

- The semantic structure [SemS] is a network whose nodes are labeled with semantemes, and arcs, or branches, with numbers of semantic dependencies - that is, predicate/ argument relations. In the diagrams of (2), both SemSs are semantic decompositions of the meaning of the sentences under analysis; the depth of these decompositions is deliberately minimal, but sufficient to make apparent the semantic relatedness of these sentences.

NB: 1. Semantemes are put in semantic quotes: 'attack', 'person', etc.

2. 'cause1' stands for non-agentive (= non-voluntary) causation; 'X causes1 $Y$ ' = ' $X$ is the cause of $Y$ '.

- The semantic-communicative structure [Sem-CommS] consists of two types of data:

- The specification of Sem-Comm-areas, which are subsets of the semantic network marked by values of some of the eight Sem-Comm-oppositions (Mel'čuk 2001: 93ff). In (2), only one of these oppositions is shown: the Sem-Rheme ( $\approx$ Comment; $\left.\mathbf{R}_{\text {Sem }}\right) \sim$ Sem-Theme ( $\approx$ Topic; $\mathbf{T}_{\text {sem }}$ ) opposition.

- The specification of the communicatively-[Sem-Comm-]dominant node of each area (underscored in the diagrams of (2); this represents the core meaning to which the meaning of the whole Sem-Comm-area can be reduced without distortion ${ }^{4}$.

The comparison of SemRs (2a) and (2b) reveals that Sentences (1a) and (1b) are not that different as they seem at first glance. Actually, we find only four semantic differences between them:

1. Different dominant Sem-Comm-nodes in the Sem-Rheme areas (the Sem-Theme areas are in one-to-one correspondence): the English sentence is about a shark attack that caused a death, while the Russian one is about a death caused by a shark attack. This correspondence is described by Sem-equivalence rule of sui generis head-switching; roughly:

$$
\begin{aligned}
& \text { ' } \underline{P} \leftarrow \mathbf{1}-\text { cause } 1-2 \rightarrow Q \text { ' } \cong \text { 'P } \leftarrow \mathbf{1}-\text { cause } 1-2 \rightarrow \underline{Q} \text { ' } \\
& P \text { that causes } Q \cong Q \text { that is.caused.by } P
\end{aligned}
$$

This “mismatch" happens because the Russian adverb SMERTEL NO 'causing1 death', semantically equivalent to FATALLY, does not co-occur with NAPADAT' '[to] attack'; with NAPADAT', Russian has to express causation of death by the complex preposition 'V REZUL'TATE' 'as a result' (= 'being.caused1.by').

2. Russian obligatorily distinguishes between two 'die'-verbs: UMERET' 'die of natural causes' and POGIBNUT' 'die of violent causes'; in other words, the components 'natural [causes]' and 'violent [causes]' are part of the respective lexicographic defini- 
tions, which ensures the appropriate selection. In English, this distinction is not obligatory and DIE is used for both non-violent and violent deaths.

3. Russian does not have a stylistically neutral noun for a "sexless" honeymooner: you have to speak either about the husband or about the wife. This information is not available linguistically (in the English sentence): you have to know who exactly was attacked - a male or a female honeymooner.

4. Russian does not have means to compactly express 'being on honeymoon'. To render the meaning of 'honeymooner', one has to say 'during the honeymoon' = vo vremja medovogo mesjaca, attaching this prepositional phrase to the Main Verb of the clause.

\subsubsection{Meaning-Text Deep-Syntactic Representation of Sentences}

(3) Deep-Syntactic Representations [DSyntRs] of Sentences (1a) and (1b)

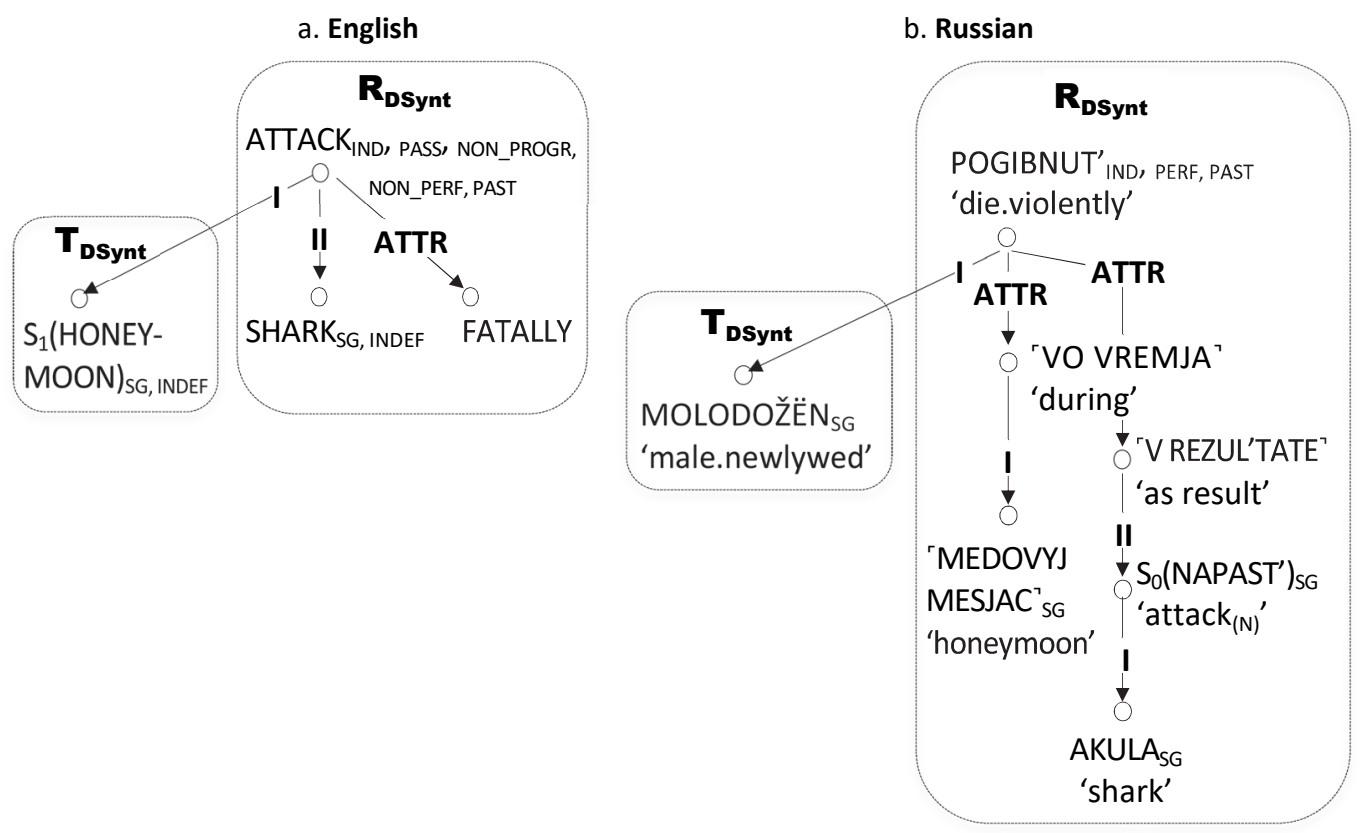

\section{Comments}

1. Like a SemR, a DSyntR consists also of four structures, two of which are of the same type as those of a SemR and two are of different types. I present here only two of DSynt-structures - those that have their counterparts in the SemR: the deep-syntactic and deep-syntactic-communicative structures. I leave out the anaphoric structure, dealing with coreferentiality of lexical units in the sentence, and the prosodic structure, which distinguishes statements from questions and exclamations, indicates irony, style and/or social register of the utterance, etc.

- A DSynt-structure [DSyntS] is a dependency tree with the following characteristics:

Its nodes are labeled with full lexical units - that is, semantically loaded lexemes and idioms. Structural ( $\approx$ auxiliary, grammatical) lexemes - such as governed prepositions and conjunctions, substitute pronouns, etc. - are not present in a DSyntS. 
Its arcs, or branches, are labeled with the names of DSynt-relations - that is, DSyntactantial numbers I, II, ...; ATTR(ibutive) modifier; etc. The DSyntRels are linguistically universal, in the sense that they are sufficient (under some additional conditions) to represent syntactic constructions of any language. Each lexical unit in the DSyntS is supplied with relevant morphological values (if any) — semantically loaded grammemes.

- A DSynt-Comm-structure [DSynt-CommS] is the specification of the subtrees marked with different Comm-values; I limit myself here to the DSynt-Rheme and DSynt-Theme areas.

2. $S_{1}$ is a lexical function (see Mel'čuk 2015: 155ff) - the general name of DSyntactant I (nomen agentis); the top corners ${ }^{\prime}{ }^{\prime}$ indicate idioms - non-compositional phraseological expressions (see Mel'čuk 2015: 293ff).

Differences between the English and the Russian DSyntRs are of two types.

First, the Russian DSyntS comprises two elements absent from the English DSyntS:

1. The complex preposition 'V REZUL'TATE' 'as a result of' (an idiom), which expresses the semanteme 'cause1', present in the meaning of the English adverb FATALLY 'causing1 death'.

2. The complex preposition 'VO VREMJA' 'during' (another idiom), which appears due to the fact that Russian lacks a nominal expression to designate the people on honeymoon and recurs to the adverbial expression 'during the honeymoon'.

Second, the Russian DSyntS has, instead of a verb with the meaning '[to] attack', the corresponding $\mathrm{S}_{0}$ (another lexical function: nomen actionis) - NAPADENIE '[an] attack'. (The selection of an action noun instead of a finite verb is imposed by the preposition 'V REZUL'TATE'.)

\subsubsection{Meaning-Text Surface-Syntactic Representation of Sentences}

(4) Surface-Syntactic Representations of Sentences (1a) and (1b)

a. English

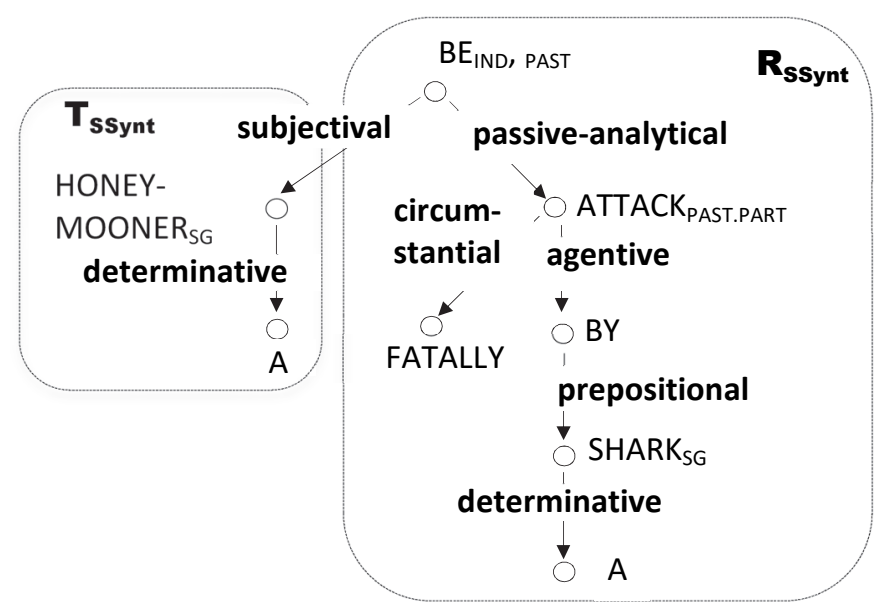




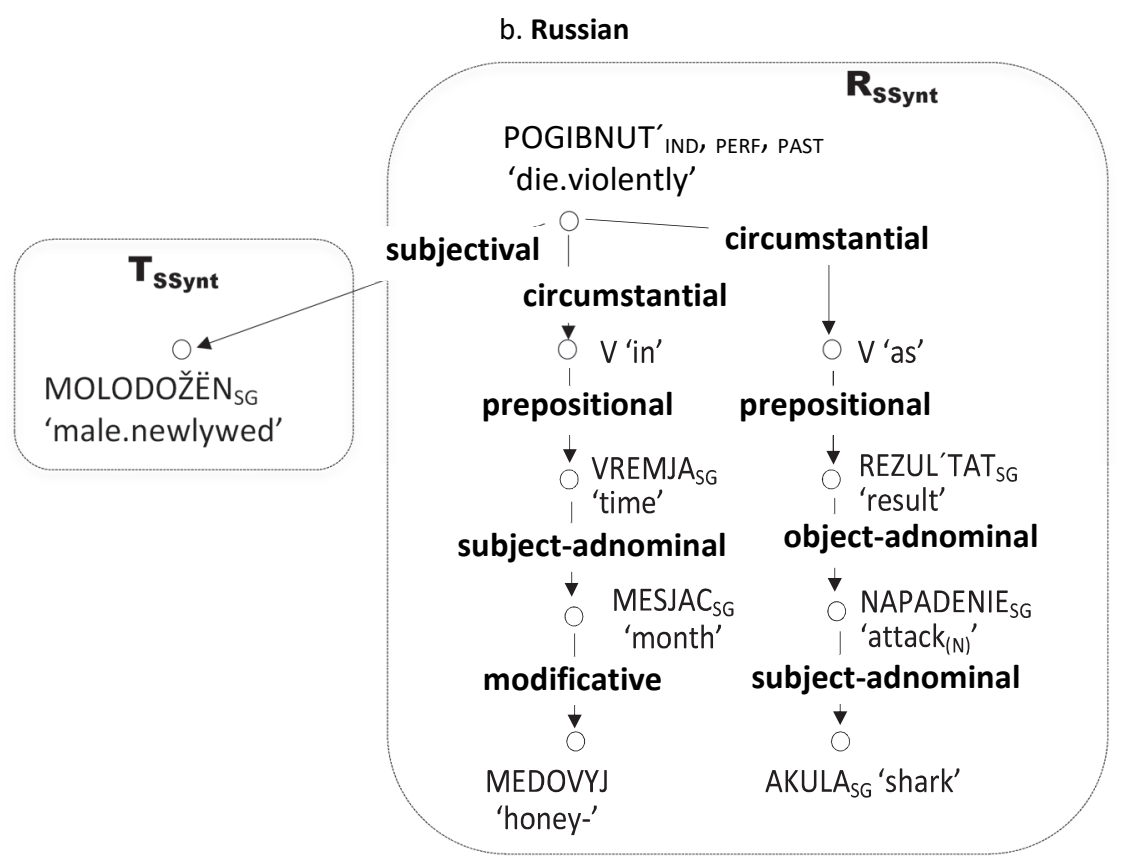

\section{Comment}

The SSyntR is similar to the DSyntR: it consists of four structures of the same type fulfilling the same functions.

The SSyntS is also a dependency tree, which, however, shows a labeling different in regard to the DSyntS:

- Its nodes carry the names of all lexemes of the sentence, including all so-called structural lexemes.

- Its branches are labeled with the names of surface-syntactic relations [SSyntRels] of the language; tentative lists of SSyntRel of English and Russian can be found, respectively, in Mel'čuk 2016: 184-194 and Mel'čuk 2012a: 135-144 (today, both lists need revision).

\subsubsection{Meaning-Text Deep-Morphological Representation of Sentences}

(5) Deep-Morphological Representations of Sentences (1a) and (1b)

a. English

$$
\text { A HONEYMOONER }_{S G} \text { | BE IND, PAST,SG FATALLY ATTACK } \text { PAST_PART }_{\text {I BY A SHARK }} \text { II }
$$

b. Russian

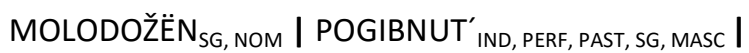




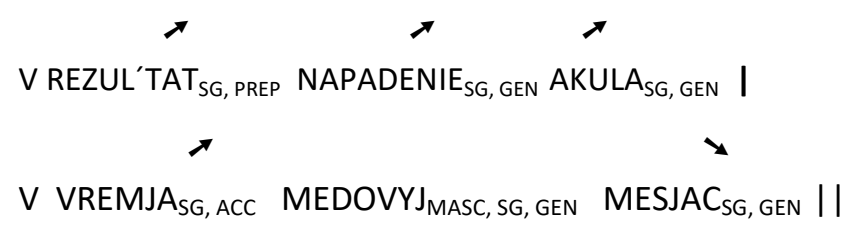

\section{Comment}

A sentence's DMorphR consists of two structures:

- The DMorphS is a string of DMorphRs of linearly ordered single lexemes, supplied, where necessary, with all grammemes (semantically loaded, coming from the DSyntS, and syntactically imposed — that is, introduced by government and agreement).

- The DMorph-ProsodicS is the set of markers for shorter/longer pauses (|, \|) and intonation rising/falling contours $(\boldsymbol{\nearrow}, \mathbf{y})$.

\subsection{Meaning-Text Formal Linguistic Rules}

I will present here rules that describe each of the three correspondences:

$\begin{array}{llc}\text { semantic representation } & \Leftrightarrow & \text { deep-syntactic representation } \\ \text { deep-syntactic representation } & \Leftrightarrow & \text { surface-syntactic representation } \\ \text { surface-syntactic representation } & \Leftrightarrow & \text { deep-morphological representation }\end{array}$

Accordingly, there are three types of linguistic rules: semantic, deep-syntactic, and surface-syntactic. (Since sentence representations closer to surface are not discussed, rules dealing with these representations are not shown.)

Given the genre of the present text, only a couple of sample rules will be given for each rule type.

\subsubsection{Meaning-Text Semantic Rules}

In the first place, Meaning-Text semantic rules lexicalize and arborize the semantic network:

- They select, for the given semantemes and semanteme configurations, the lexical units to be put into the DSynt-structure (Rule ${ }^{\text {Sem }} \mathbf{1}$ in our illustration).

- They compute, for the given SemRels, the corresponding DSynt-branches or more complex expressions-DSynt-subtrees (Rule ${ }^{\mathrm{Sem}} \mathbf{2}$ for Russian).

The Sem-rules also take care of several other aspects of the SemR $\Leftrightarrow$ DSyntR correspondence - such as computing the top node (= head) of the syntactic tree of the sentence and the morphological values (grammemes), transposing Sem-Commareas, etc. - but these tasks are not considered here. 
(6) $\operatorname{SemR} \Leftrightarrow$ DSyntR

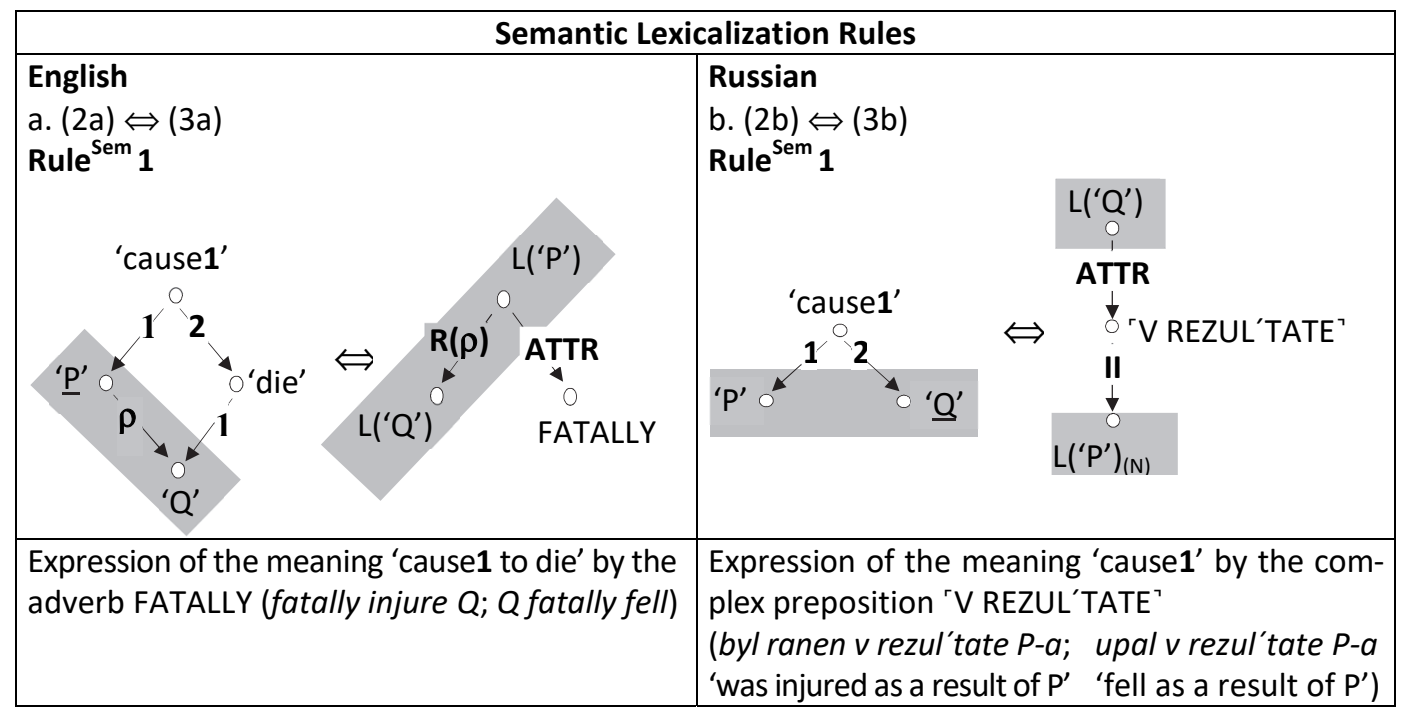

\section{Comments}

1. The shaded region indicates the context of a rule: the part of this rule which is not affected by it, but whose presence in the respective representation is necessary for the rule to apply.

2. L(' $\Psi$ ') stands for "lexical unit expressing the meaning ' $\Psi$ '."

3. $\rho$ is a particular SemRel, $\mathbf{R}(\rho)$ - a DSyntRel that corresponds to $\rho$.

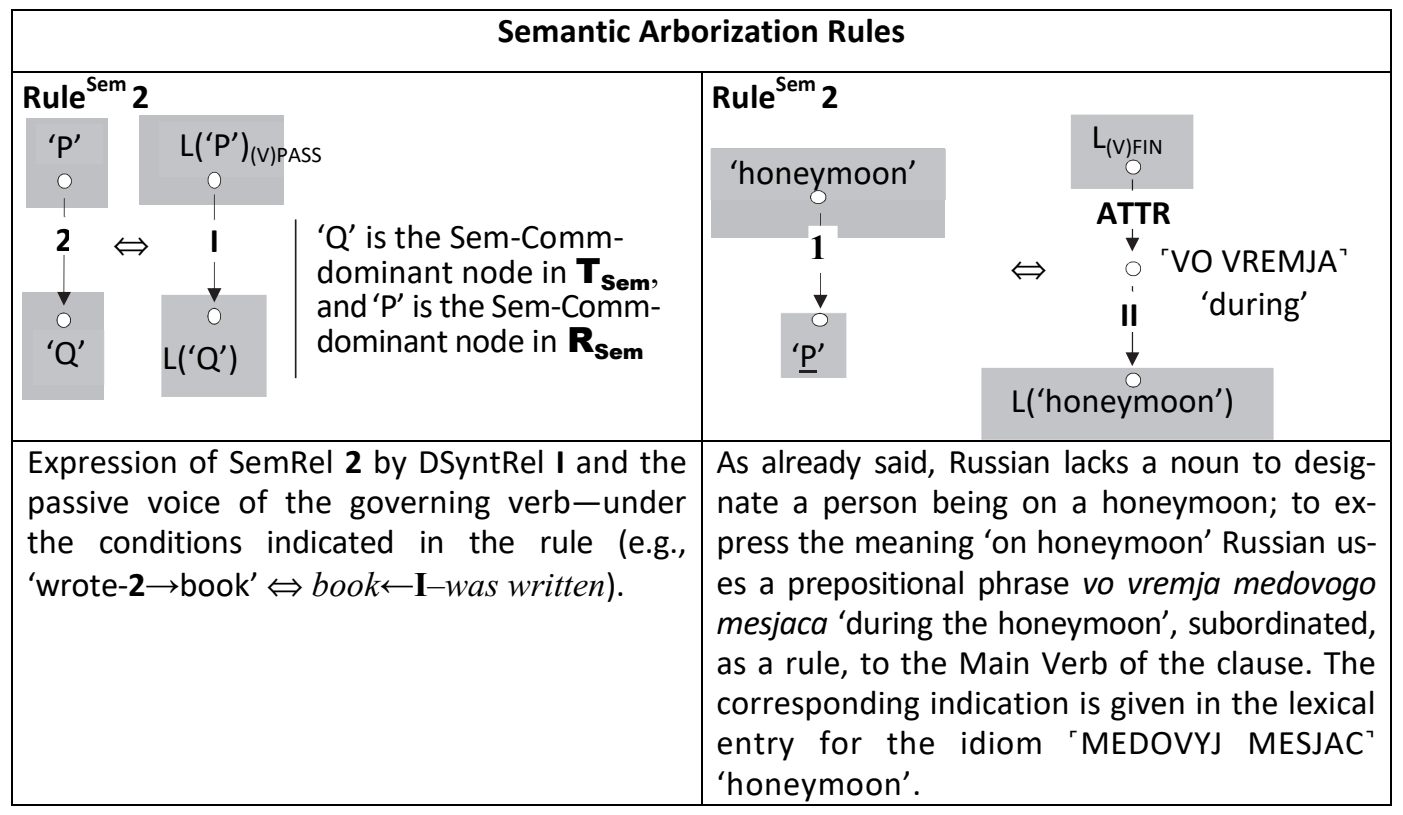

Sem-rules of the first type - that is, lexicalization Sem-rules - correspond to the lexical entries of a lexicon of a special type, known as Explanatory Combinatorial Dictionary (mentioned in 3.1, p. 524). 


\subsubsection{Meaning-Text Deep-Syntactic Rules}

Meaning-Text deep-syntactic rules "adapt" the given DSyntR to the surfacesyntactic requirements of the language in question.

On the lexical side, they sharpen the lexicalization by computing the values of lexical functions (English Rule ${ }^{\text {DSynt }} \mathbf{1}$ ) and developing the node of an idiom into the corresponding SSynt-subtree (Russian Rule ${ }^{\text {DSynt }} \mathbf{1}$ ); they also do several other things (e.g., develop the nodes of analytical forms into subtrees), which I leave out of consideration.

On the syntactic side, DSynt-rules complete arborization: associate DSyntRels with their SSynt-expressions.

(7) DSyntR $\Leftrightarrow$ SSyntR

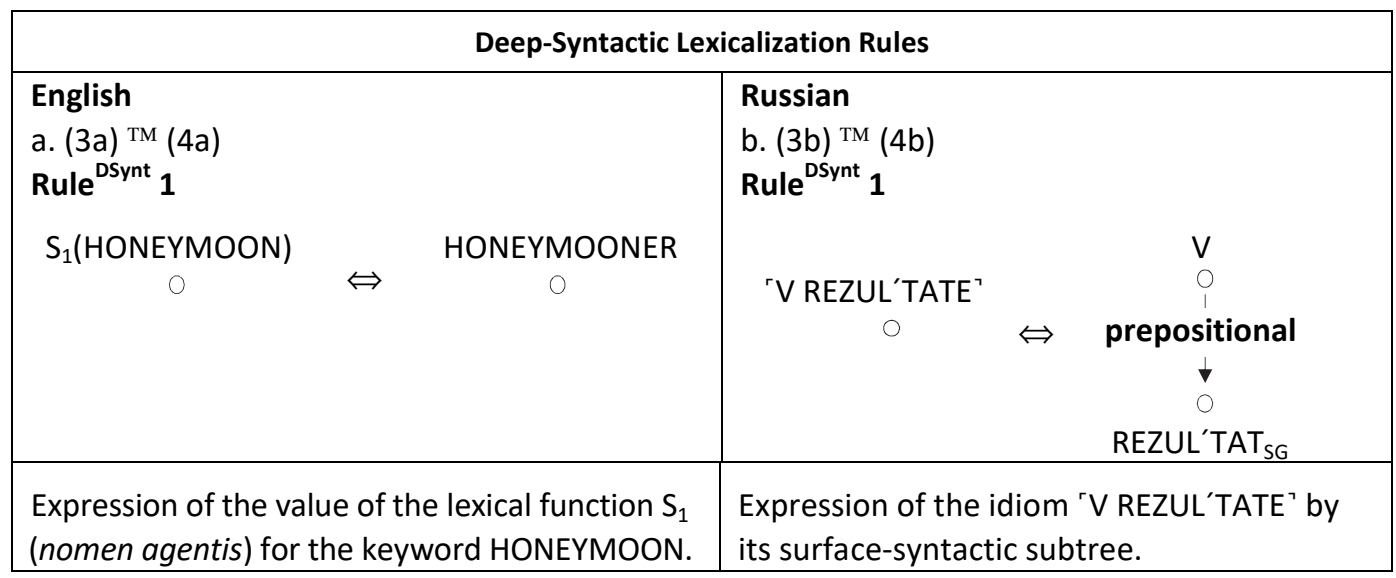

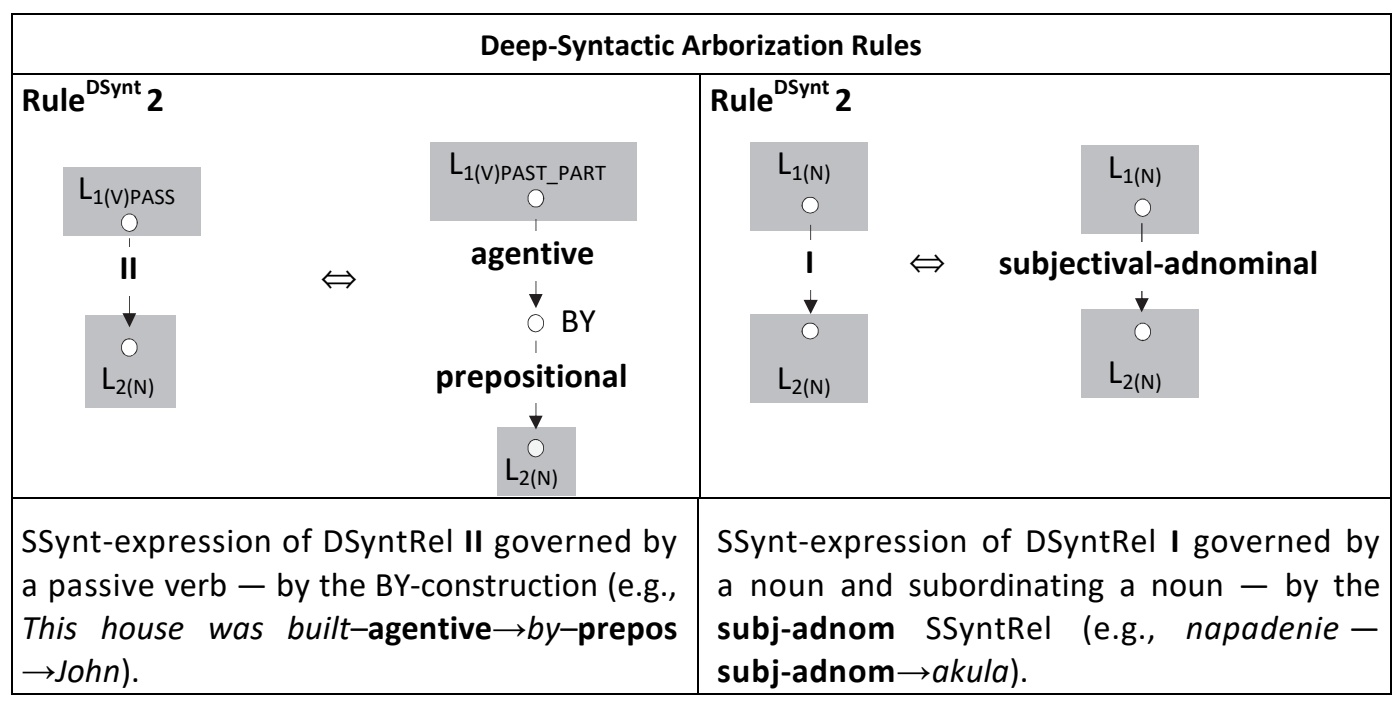

\subsubsection{Meaning-Text Surface-Syntactic Rules}

Meaning-Text surface-syntactic rules carry out linearization and morphologization (of the lexemes present in the given SSynt-structure). 
(8) $\operatorname{SSyntR} \Leftrightarrow$ Deep-MorphR

Surface-Syntactic Linearization and Morphologization Rules

English

a. $(4 a) \Leftrightarrow(5 a)$

Rule $^{\text {SSynt }} 1$

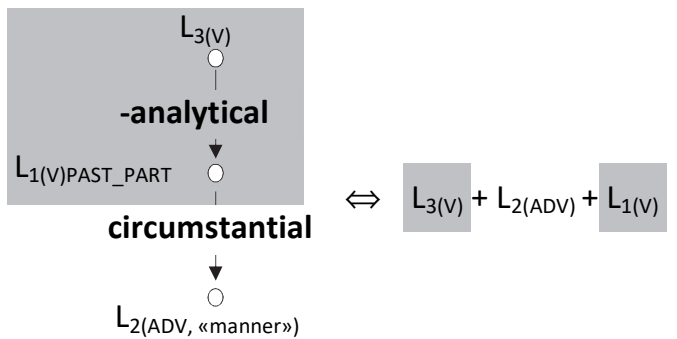

Linear placement of an adverb of the FATALLY type.

"-analytical" stands for passive-analytical and perfect-analytical SSyntRels.

\section{Russian}

b. $(4 b) \Leftrightarrow(5 b)$

Rule $^{\text {SSynt }} 1$

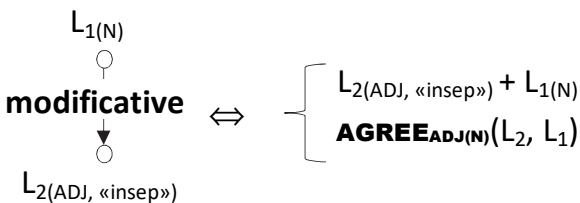

Linear placement and morphologization of the adjective MEDOVYJ 'honey-'.

1. The adjective receives the syntactic feature «insep(arable)» in the transition from the DSyntS to the SSyntS, when an idiom is developed into its full SSynt-subtree.

2. $A_{G R E E_{A D J(N)}}$ is an agreement operator that is, a set of rules that take care of agreement of an $A D J$ with the $\mathrm{N}$ on which the ADJ depends.

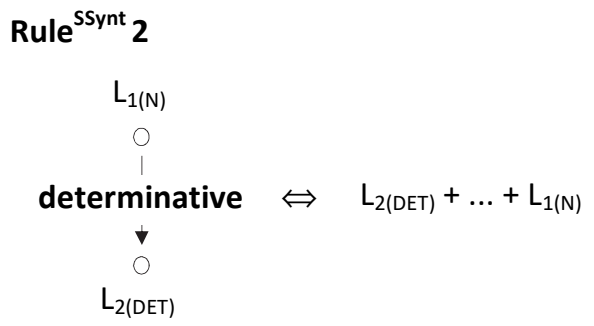

Linear placement of a determiner (A, THE, THIS, etc.).

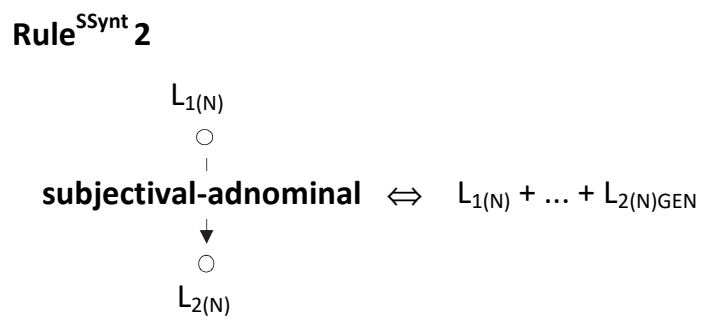

Linear placement and morphologization (= supplying the GEN grammeme) of a noun being the subjectival adnominal complement (in this case, AKULA 'shark').

\section{Comments}

1. The "+" symbol indicates the linear order; "..." stands for a possible gap between the two elements being linearized (the complete version of linearization rules contains the constraints on what can be positioned in this gap).

2. The linearization SSynt-rules also include standard patterns for simple and complex phrases; the rules given above as illustration compute the position of elements based on these patterns.

$$
* * *
$$

Much more can be said about rich and variegated results obtained in linguistics due to semantic decomposition. But what has been said seems sufficient to show how far have gone AW's ideas about semantic decomposition. More power to them - and to her! 


\section{FIFTY-FIVE YEARS AGO}

Lest I forget... A sweltering afternoon, early September 1963 in Sofia, Bulgaria, the $\mathrm{V}^{\text {th }}$ International Congress of Slavists. I have just finished my talk about automatic syntactic analysis of Russian using dependency syntactic representation. A group of audience members is bombarding me with questions and remarks. Among them, a very young woman, looking like a high school student, svelte and elegant, in a light blue dress and blue bandanna in her light brown hair. She speaks Russian, with a charming Polish accent, and her questions are excellent - to the point, clear and trenchant, showing her complete understanding of the matter (a rare phenomenon at linguistic gatherings). I am swept of my feet and offer her - not my hand and my heart, since I am fully and happily married - but a hiking adventure: to go on foot right away to the summit of the Vitosha Mountain, which dominates Sofia. She accepts without blinking and off we go! We have to hurry, since the same night at 7 PM we are supposed to be at the huge banquet offered to the congress participants by our Bulgarian hosts. (And to boot, I received a note from a colleague, with whom I was not acquainted personally, - a Rumanian mathematician, Professor Grigore Moisil, who invited me to join him at the banquet. In order for me to recognize him, he wrote in Russian: Kogda uvidite sil'no žrajuščego ${ }^{5}$ čeloveka, èto budu ja lit. 'When you see a strongly gobblin' man, this will be me'.) The climb proved tougher than I had believed, and we reached the summit after 7... We had no Bulgarian money, and we could not take a cab, but had to run. And lo and behold! When we reached the practically empty banquet hall, we saw "a strongly gobblin' man", who turned out, of course, to be Moisil and who had hoarded for us a huge selection of different luscious dishes and drinks. We finished the evening in a pleasant and reinvigorating conversation about linguistics and, in particular, semantics. That is how my friendship with Anna Wierzbicka started.

NB: The reader can be expected to wonder what is the logical link between Section 4 and the preceding text. Sorry, no link whatsoever. It is simply very pleasant for me to reminisce...

(C) Igor Mel'čuk, 2018

\section{REFERENCES}

Apresjan, Jurij. (1974). Leksičeskaja semantika. Sinonimičeskie sredstva jazyka [Lexical Semantics. Synonymic Means of Language]. Moscow: Nauka.

Apresjan, Yuri. (1992). Lexical Semantics. User's Guide to Contemporary Russian Vocabulary. Ann Arbor, MI: KAROMA.

Apresjan, Jurij, ed. (2014). Aktivnyj slovar' russkogo jazyka [Active Dictionary of Russian]. Avtory: V.Ju. Apresjan, Ju.D. Apresjan, E.È. Babaeva, O.Ju. Boguslavskaja, I.V. Galaktionova, M.Ja. Glovinskaja, B.L. Iomdin, T.V. Krylova, I.B. Levontina, A.A. Lopuxina, A.V. Ptencova, A.V. Sannikov, E.V. Uryson. Volumes 1-2. Moscow: Jazyki slavjanskoj kul'tury.

Apresyan, Yuri, Mel'čuk, Igor \& Žolkovsky, Alexander. (1969). Semantics and lexicography: Towards a new type of unilingual dictionary. In: F. Kiefer, ed., Studies in Syntax and Semantics, Dordrecht: Reidel, 1 -33.

Goddard, Cliff \& Wierzbicka, Anna. (2014). Words and Meanings. Lexical Semantics across Domains, Languages, and Cultures. Oxford: Oxford University Press. 
Mel'čuk, Igor. (1974). Opyt teorii lingvističeskix modelej "Smysl $\Leftrightarrow$ Tekst". Semantika, sintaksis [Outline of a Theory of Meaning-Text Linguistic Models. Semantics and Syntax]. Moscow: Nauka.

Mel'čuk, Igor. (2001). Communicative Organization in Natural Language. Amsterdam/Philadelphia: John Benjamins.

Mel'čuk, Igor. (2012a). Jazyk: ot smysla k tekstu [Language: From Meaning to Text]. Moskow: Jazyki slavjanskoj kul'tury.

Mel'čuk, Igor. (2012b. Semantics: From Meaning to Text. Vol. 1. Amsterdam/Philadelphia: John Benjamins.

Mel'čuk, Igor. (2013). Semantics: From Meaning to Text. Vol. 2. Amsterdam/Philadelphia: John Benjamins.

Mel'čuk, Igor. (2015). Semantics: From Meaning to Text. Vol. 3. Amsterdam/Philadelphia: John Benjamins.

Mel'čuk, Igor. (2016). Language: From Meaning to Text. Moskow/Boston: Academic Studies Press.

Mel'čuk, Igor \& Zholkovsky, Alexander. (1984). Explanatory Combinatorial Dictionary of Modern Russian. Vienna: Wiener Slawistischer Almanach. See also:

http://olst.ling.umontreal.ca/pdf/Melcuk_Zholkovsky_1984.pdf.

Mel'čuk, Igor' \& Žolkovskij, Aleksandr. (2016). Tolkovo-kombnatornyj slovar' russkogo jazyka. 2-oe izdanie, ispravlennoe. Moscow: Jazyki slavjanskix kul'tur.

Padučeva, Elena. (1996). Fenomen Anny Vežbickoj [Anna Wierzbicka’s Phenomenon]. In: Vežbickaja, Anna, Jazyk. Kul'tura. Poznanie, Moscow: Russkie slovari, 5-32.

Wierzbicka, Anna. (1972). Semantic Primitives. Frankfurt am Main: Athenäum.

Wierzbicka, Anna. (1988). The Semantics of Grammar. Amsterdam/Philadelphia: John Benjamins.

Wierzbicka, Anna. (1992). Semantics, Culture, and Cognition. Universal Human Concepts in CultureSpecific Configurations. New York/Oxford: Oxford University Press.

Wierzbicka, Anna. (2001). What Did Jesus Mean? Explaining the Sermon on the Mount and the Parables in Simple and Universal Human Concepts. Oxford: Oxford University Press.

Wierzbicka, Anna. (2014a). Imprisoned in English. The Hazards of English as a Default Language. Oxford: Oxford University Press.

Wierzbicka, Anna. (2014b). Can there be common knowledge without a common language? German Pflicht versus English Duty. Common Knowledge, 21 (1), 140-171.

Wierzbicka, Anna. (2018). Speaking about God in universal words, thinking about God outside English. In: Paul Chilton and Monika Kopytowska (eds.), Religion, Language, and the Human Mind, 19-51. Oxford: Oxford University Press.

Wierzbicka, Anna (2018). Emotions of Jesus. Russian Journal of Linguistics, 22 (1), 38-53. doi $10.22363 / 2312-9182-2018-22-1-38-53$

Žolkovskij, Aleksandr. (1964a). Predislovie [Foreword]. Mašinnyj perevod i prikladnaja lingvistika, $8,3-16$.

Žolkovskij, Aleksandr. (1964b). O pravilax semantičeskogo analiza [Rules for semantic analysis]. Mašinnyj perevod i prikladnaja lingvistika, 8, 17-32.

Žolkovskij, Aleksandr. (1964c.) Leksika celesoobraznoj dejatel'nosti [Vocabulary of teleological activity]. Mašinnyj perevod i prikladnaja lingvistika, 8, 67-103.

Žolkovskij, Aleksandr, Leont'eva, Nina \& Martem'janov, Jurij. (1961). O principial'nom ispol'zovanii smysla pri mašinnom perevode [On an essential use of meaning in machine translation]. In: Mašinnyj perevod, vol. 2, Moscow: Institut točnoj mexaniki i vyčislitel'noj texniki AN SSSR, $17-46$ 
NB: For English translations of Zholkovsky's papers, see Rozencvejg, V. (ed.) (1974), Essays on Lexical Semantics, Stockholm: Skriptor; and Rozencvejg, V. (ed.) (1974), Machine Translation and Applied Linguistics, Frankfurt am Main: Athenaion Verlag.

Žolkovskij, Aleksandr \& Mel'čuk, Igor'. (1965). O vozmožnom metode i instrumentax semantičeskogo sinteza [On a possible method and some tools of semantic synthesis]. Naučno-texničeskaja informacija, 5, 23-28.

Žolkovskij, Aleksandr \& Mel'čuk, Igor'. (1966). O sisteme semantičeskogo sinteza. I. Stroenie slovarja [A system for semantic synthesis. I. The structure of the dictionary]. Naučno-texničeskaja informacija, 11, 48-55.

Žolkovskij, Aleksandr \& Mel'čuk, Igor'. (1967). O semantičeskom sinteze [On semantic synthesis]. Problemy kibernetiki, 19, 177-238.

\section{NOTES}

1 And also established the best formula for genuine Russian vodka: $40 \%$ alcohol ensures the best cost/taste/effect ratio.

${ }^{2}$ In the process, AW defined the concept of GOD: Wierzbicka 2001: 21 and 2018 (I owe the most recent reference to my Anonymous Reviewer). I cannot help quoting the latest definition in full:

(a) there is someone not like people*

(b) this someone is someone above people

(c) this someone is someone above everything

(d) this someone is now, always was, always will be

(e) this someone is everywhere

(f) there is no one else like this someone

(h) God is this someone**

* The component 'someone' of Wierzbicka's definition seems to clash with the official position of the Swedish Church: in November 2017, they decided that God is - or at least must be referred to - as $I t$, which corresponds rather to 'something'. By all means, a 'someone' necessarily is of the one of two sexes. A natural question rises right away...

** I am theologically ignorant, but isn't it true that one of the attributes of the Christian God is goodness?

Given the utmost importance of the whole problem, I consider it appropriate and useful to give here the previous definition of God as well:

God

(a) God is someone (not something)

(b) this someone is someone good

(c) this someone is not someone like people

(d) there is not someone else like this someone

(e) this someone exists always

(f) everything exists because this someone wants it to exist

(g) people exist because this someone wants them to exist

(h) everything exists because this someone exists, not because of anything else

(i) this someone lives 
3 The two Giants of Contemporary Semantics:

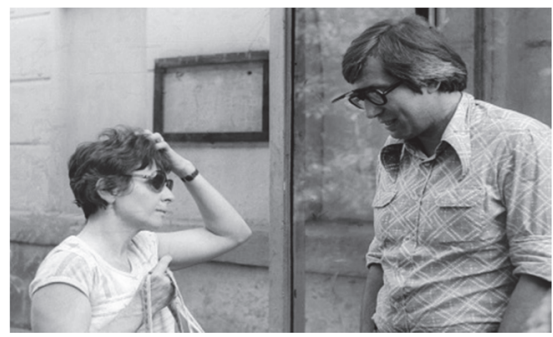

Anna Wierzbicka with Alik Žolkovskij

in Moscow, in 1965 - probably,

discussing semantic decomposition.

${ }^{4}$ One of important particularities of the Meaning-Text approach is a consistently drawn distinction between the semantic CommS (Comm-organization of the starting meaning) and the syntactic CommS (Comm-organization of the sentence as represented by its deep-syntactic and surface-syntactic structures), see the representations in (2)-(4).

${ }^{5}$ It is exactly how it was spelled in Moisil's note: “сильно жрающего человека".

\section{Article history:}

Received: 20 March 2018

Revised: 15 May 2018

Accepted: 27 May 2018

\section{История статьи:}

Дата поступления в редакцию: 20 марта 2018

Дата принятия к печати: 27 мая 2018

\section{For citation:}

Mel'čuk, Igor (2018). Anna Wierzbicka, Semantic Decomposition, and the Meaning-Text Approach. Russian Journal of Linguistics, 22 (3), 521 — 538. doi: 10.22363/2312-9182-2018-22-3-521-538.

\section{Для цитирования:}

Mel'čuk I. Anna Wierzbicka, Semantic Decomposition, and the Meaning-Text Approach // Вестник Российского университета дружбы народов. Серия: Лингвистика = Russian Journal of Linguistics. 2018. T. 22. № 3 C. 521-538. doi: 10.22363/2312-9182-2018-22-3-521-538.

\section{Bio Note}

IGOR MEL'ČUK is Professor Emeritus at the University of Montreal, Canada, the author of 47 books and 279 published scientific papers. His research interests include general linguistics (with special attention to its conceptual apparatus and terminology), semantics (with special attention to lexicology and lexicography), syntax (with special attention to dependency structures), and morphology; his work is based mostly on Russian and French, but concerns also English and several other languages (Hungarian, Lezghian, Alutor, Dyirbal, Bafia, Kirundi, Korean). He is the proponent of the MeaningText approach to natural language and one of the pioneers of Machine Translation — since 1954.

Contact information: E-mail: igor.melcuk@umontreal.ca

\section{Сведения об авторе:}

ИГОРЬ МЕЛЬЧУК - заслуженный профессор Монреальского университета (Канада), автор 47 книг и 279 научных статей. Его научные интересы включают общую лингвистику (в особенности ее понятийный аппарат и терминологию), семантику (в особенности лексикологию 
и лексикографию), синтаксис (в особенности структуры зависимостей) и морфологию. Работы И.А. Мельчука основываются, в первую очередь, на русском и французском языках, но затрагивают также английский и ряд других языков (венгерский, лезгинский, алюторский, бафия, рунди, корейский). И.А. Мельчук является автором лингвистического подхода «Смысл-Текст» и одним из пионеров машинного перевода - с 1954 года.

Контактная информация: E-mail: igor.melcuk@umontreal.ca

\section{ACKNOWLEDGMENTS}

The text of this paper was read and criticized by Jurij Apresjan, David Beck, Lidija Iordanskaja, Jasmina Milićević, and an Anonymous Reviewer. May all these nice people, whose remarks and suggestions led to an improved presentation, receive my most heartfelt gratitude!

\section{ФИНАНСИРОВАНИЕ И БЛАГОДАРНОСТИ}

Выражаю сердечную благодарность всем, кто прочитал эту статью и высказал свои замечания - Юрию Апресяну, Дэвиду Беку, Лидии Иорданской, Ясмине Миличевич и анонимному рецензенту. 